\title{
HIKING TRAILS IN MACEDONIA: ASSESSING POTENTIALS FOR TOURISM DEVELOPMENT
}

DOI: http://dx.doi.org/10.18509/GBP.2018.39

UDC: 338.48:625.734.2(497.7)

\section{Biljana Petrevska \\ Nikola Dimitrov}

Faculty of Tourism and Business Logistics, Goce Delcev University - Stip, Macedonia

\begin{abstract}
The primary objective of this study is to make analysis of the current hiking trails in Macedonia, even though following the experiential approach, light will be shed on the possibilities for developing new tourism product that may enhance tourism development in the country. Macedonia represents a suitable testing ground for such investigation having in mind that so far, more than one hundred hiking trails are identified within the draft national network of the hiking trails. Furthermore, the research combines the current hiking trails and mountain dormitories in order to try to conceptualize them as a system that may be covered with tourism patterns. The analysis is based on a qualitative research method, mainly by exploring secondary sources of information. The findings indicate an option for reshaping the current network of national trails due to additional great number of newly identified trails. Furthermore, it was found that out of forty mountain dormitories, only seven may somehow serve in tourism purposes. The most surprising is the conclusion that among large portion of hiking trails no usable dormitory is present, which challenges construction of new or complete restauration of the old ones. Besides official documents and some isolated positive examples of private initiatives which pose some insights, no academic studies have so far been carried out on this issue. Therefore, this research contributes to the literature as a pioneer study in Macedonia's academic work, along with its practical significance. Namely, it suggests many recommendations towards the necessity of inducing more proactive attitude among tourism policy makers for designing new tourism product as an important component of tourism supply.
\end{abstract}

Keywords: Hiking trails; Mountains; Tourism development; Macedonia.

\section{INTRODUCTION}

Mountains are often used as resources for developing tourism, in the first line by offering pleasure, relaxation, sport activities or even enjoying spiritual and psychological needs [2], [7], [8], [13], [14], [15], [16] and [18]. Many valuable information and experience on mountain tourism development may be gained from countries that implement mountain tourism, such as Austria, Switzerland, Germany, France, Italy, Slovenia, Serbia and others [2] and [3]. In this line, many countries have realized the benefits for mountain tourism development. Yet, possessing mountains does not automatically mean gaining economic benefits. What is required for a successful mountain tourism development is actually a significant investment of time, money and efforts.

Consequently hiking is detected as a form of activity that attracts tourists greatly and trails are defined as a linkage between visitors and ecosystems. So many academicians discuss the relevance and potentials of hiking as a tourist activity [10] and [12], as well 
as the impacts that hiking as a wellness activity is provoking to the nature related to tourism development [5], [11] and [17]. Moreover, [9] Hugo discusses that hiking trails should furthermore not be seen as mere links between places, but as part of a holistic integrated person-environment system.

Being identified as a country rich in mountains, Macedonia possesses excellent preconditions for developing mountain tourism. It has seven active ski centers with 42 ski-elevators, offers possibilities for active mountaineering due to dormitories, hotels and guest houses, and it has pleasant tracks for mount-biking, paragliding, etc. On the other hand, the current conditions for developing mountain tourism in Macedonia are generally poor due to severe infrastructural problems [4].

The objective of this study is to present some stylized facts and make analysis of the current hiking trails in Macedonia, thus making an effort to explore possibilities for developing new tourism product that may enhance tourism development in the country. The focus of the investigation is put on more than one hundred hiking trails which are already identified within the draft national network of the hiking trails [1]. Furthermore, the study criticizes the only official governmental document that treats the issue of hiking trails in Macedonia.

The paper is structured in several parts. After the introductory part, Section two presents the research methodology. The analysis, results and discussion are noted in Section three, while the conclusion remarks and recommendations are presented in the last section.

This study contributes to the limited academician work on hiking tourism in Macedonia. At the same time, it has its practical significance since it provides recommendations for inducing more proactive attitude among tourism policy makers in terms of designing new tourism product as an important component of tourism supply of Macedonia.

\section{RESEARCH DESIGN}

The study attempts to review the current hiking trails in Macedonia by following the experiential approach. The analysis is based on a qualitative research method, mainly by exploring secondary sources of information. In general, there is an abundance of available data and statistical surveys that can be used to trace the development of hiking trails in Macedonia, as well as to assess their significance for tourism development. Herein, the available data are collected from the Draft national network on hiking trails in Macedonia [1], and analyzed to obtain information about the national level and, if necessary, the regional level.

All collected information is summarized and graphically interpreted as maps. The maps provide general information on the type of the hiking trail according to the level of difficulty, ranging from recreational, beginners', medium, advanced to a very professional hiking trail. Furthermore, to get a picture of the tourism supply related to the hiking trails, the maps are complemented with data on accommodation infrastructure in terms of mountain dormitories. For this purpose, the available data are analyzed based on [4] Dimitrov et al. The compilation of both types of data allows to conduct the research. The evaluation is presented in graphical form by production of four maps which enable to visualize the results in a way that makes it possible to see the different flows. Based upon results, the authors derive specific conclusions and recommendations as to how current hiking trails and the mountain dormitories concerned, may improve further tourism development. 


\section{FINDINGS AND DISCUSSION}

The findings are analyzed by mapping flows of hiking trails described in the official document [1]. Figure 1 presents more than a hundred hiking trails marked upon the level of difficulty of the tour and required level of physical fitness. The green dots represent recreational hiking trails which are very easily manageable since they are only up to 5 $\mathrm{km}$, usually take up to 3 hours to be accomplished and require very low level of fitness. Although this type of trails is extremely tourist-friendly, according to Figure 1, Macedonia offers just a few of them. On the other hand, it may be visualized that yellow dots are much more present on the map. They represent the beginners' trails which alike the recreational, are also very easy to accomplish. Hence, one may say that recreational and nature-lover tourists do have trails to hike in Macedonia. The focus is on the orange dots which represent medium trail difficulty with a hiking length between $5-10 \mathrm{~km}$, duration between 3-6 hours and a demand of a moderate level of physical condition. Most probably the high hills that Macedonia is rich in, present a suitable ground for these types of trails. Much harder level of difficulty shows the advanced trails (red dots on Figure 1), suitable only for very experienced hikers and tourists. They usually cover $10-15 \mathrm{~km}$ trails, last 6-10 hours and demand a very high body condition. The fewest are the professional hiking trails which are the most advanced (black dots on Figure 1). These routes are more than $15 \mathrm{~km}$ long and last over 10 hours. The hikers hike on trails spreading over the altitude over $1,500 \mathrm{~m}$. and therefore, an extra body shape and condition is a must.

If we put a good look on the country's coverage with hiking trails, it is very obvious that they are predominantly dispersed in the west part of Macedonia, rarely in the central part, and barely in the east part. Due to the fact that Macedonia has many mountains in other parts besides the western, leaves a space for future research upon update of the official documents which address this issue.

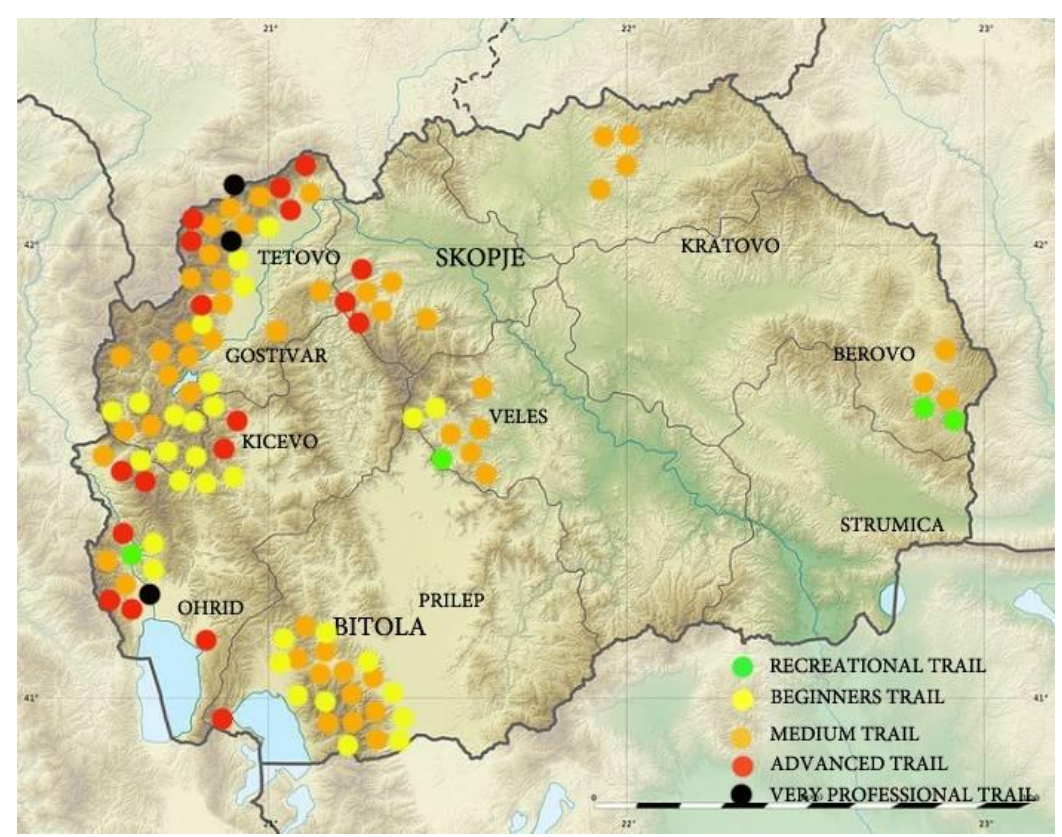

Figure 1. Hiking trails in Macedonia

Source: Own illustrations based upon [1], graphics @2017 Google maps

Figure 2 presents around forty mountain dormitories in Macedonia based upon the findings declared in [4] Dimitrov et al. According to the condition in which they are, the 
mountain dormitories are perceived as old and new. The old mountain dormitories (mapped with brown icons on Figure 2) are in a bad shape and some have being inoperative for many years. It is noticeable that they are dispersed all over the territory of Macedonia, thus presenting a good starting point as accommodation infrastructure that may complement a hiking tour. However, this may only be the case if the government (local/regional/central) or the private sector, decides to make some serious investments. So, although they are old, they can be adopted and renovated in order to serve the tourist purposes.

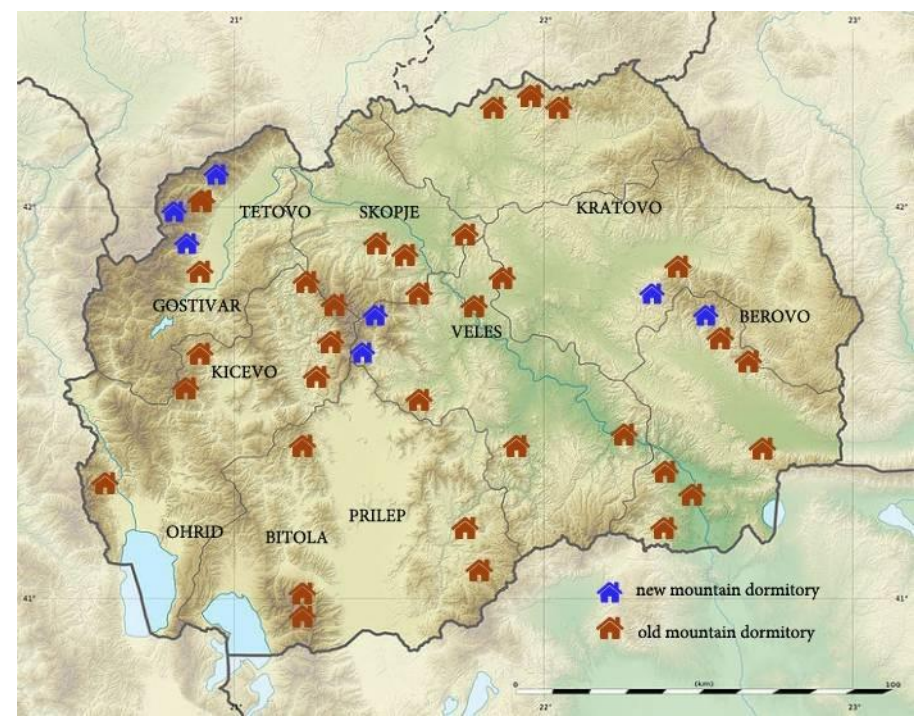

Figure 2. Mountain dormitories in Macedonia

Source: Own illustrations based upon [4], graphics (C2017 Google maps

On the other hand, the blue icons in Figure 2, present the new mountain dormitories, being hardly seven: Vrteska and Dzumaja (Plackovica), Sharski Vodi, Smreka and Ljuboten (Shar Planina), Papradishte and Karadzica (Jakupica).

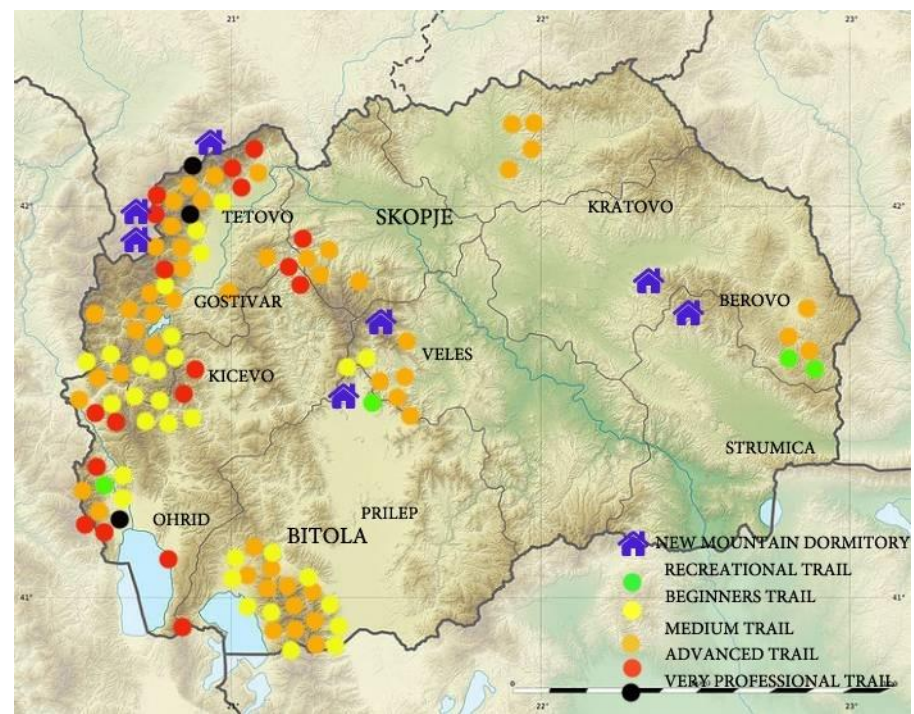

Figure 3. Hiking trails and new dormitories in Macedonia Source: Own illustrations, graphics @2017 Google maps 
Figure 3 combines the hiking trails (data from Figure 1) and the new mountain dormitories (partial data from Figure 2). The intention is to identify whether there is a match among the current trails and dormitories usable for tourist purposes. More precisely, the idea is to describe the possibility to combine these two items and to try to conceptualize them as a system that may be covered with tourism patterns. It is noticeable that five out of seven new mountain dormitories fit into the currently identified hiking trails. The other two dormitories (Vrteska and Dzumaja on mountain Plackovica), although being in a good shape and may work with full capacity, are not near the identified hiking trails mapped in the east part of Macedonia. This raises the issue of a mismatch between the supply and demand.

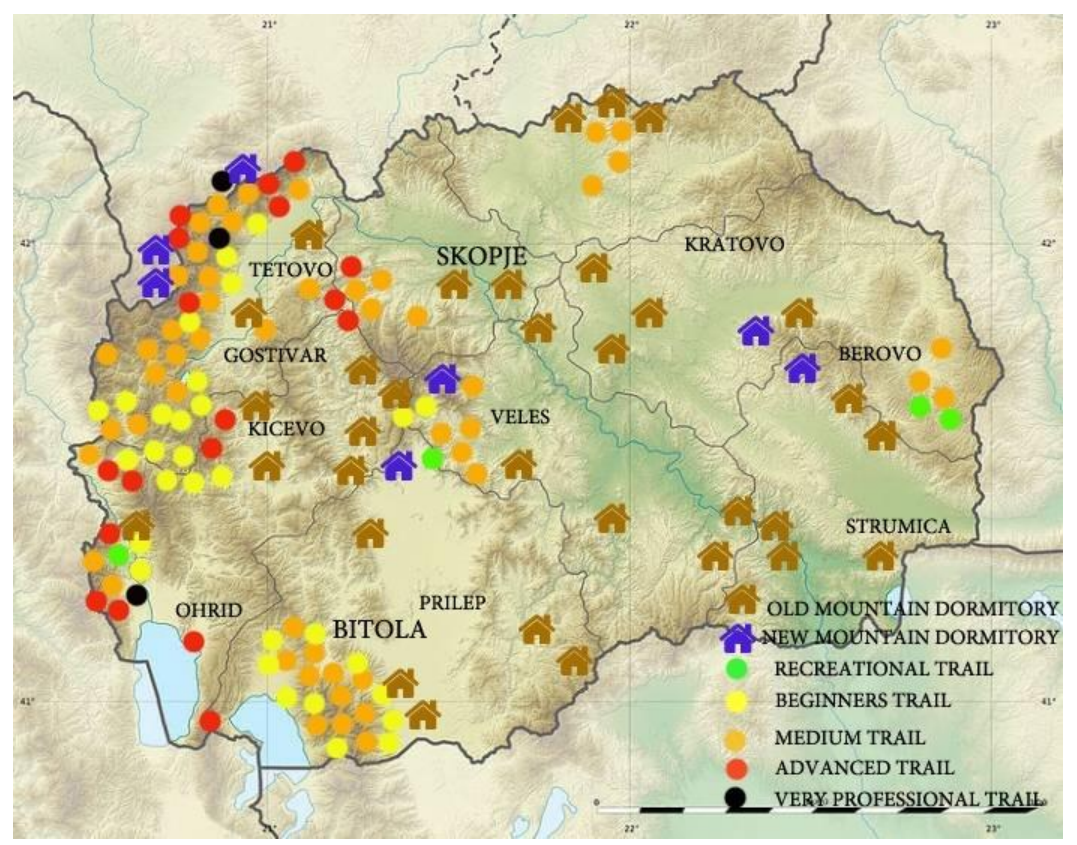

Figure 4. Hiking trails and all dormitories in Macedonia

Source: Own illustrations, graphics (C2017 Google maps

Finally, based on Figure 1 (data on hiking trails) and Figure 2 (full data on mountain dormitories), Figure 4 is produced. It presents all officially identified hiking trails along with all dormitories (old and new). This figure gives a clear picture that many new hiking trails are actually missing, and the old dormitories need an urgent reconstruction in order to serve as a solid precondition for setting new hiking trails. In this manner, the authorities may consider the option for introducing subsidies for private project actions in the line of renewing the old accommodation capacities. Furthermore, this finding indicates an option for reshaping the current network of national trails due to a great additional number of newly identified trails. Yet, the most surprising is the conclusion that among large portion of hiking trails there is no usable dormitory present, which challenges the construction of a new or complete restoration of the old ones.

\section{CONCLUSION AND RECOMMENDATION}

The research intended to identify the current hiking trails in Macedonia in accordance to the only official governmental document on this issue, and their coverage with mountain dormitories. The main idea was to combine and conceptualize them as a system that may 
be covered with tourism patterns, upon which valuable recommendations will be given for designing a new tourism product as an important component of the country's tourism supply. However, looking from the perspective of the developmental policy, one may see that the gathered data provide very little information which could be used to assess the large-scale impacts on tourism development. On the other hand, this is precisely the kind of insights needed to develop tourism development strategies and to value the chain approaches in tourism, and to find some appropriate solutions for the national tourism.

Out of more than forty dormitories, due to the lack of finance, only seven are identified as new facilities in good shape. The tight budget and inadequate financial resources for reconstructing mountain dormitories as a result of the lack of funds and interest of the local, regional and central government, as well as the absence of private initiative, are among the most serious challenges to face with. The central government has the responsibility to continuously provide the basic funding for the management and infrastructure maintenance in the national parks and protected areas that are full of hiking trails (such as through conservation- or tourism-related taxes). Yet, some future terms might also increasingly require private-capital investments. Finally, the tourists themselves (as visitors, day-trippers, nature-lovers etc.) play a key role in this regard because they are among the primary beneficiaries of the nature, and thus have a major strategic interest in making an appropriate contribution to the financial viability of the mountain areas.

At this stage, the hiking trails do not play a substantial role in the country's tourism development despite the potentials. In order to make this segment more attractive some complex processes are required mostly in the implementation of the tourism policies. This stands for very demanding institutional requirements so that they would ensure that tourism development is based on considerations of effectiveness, efficiency and transparency.

To give appropriate consideration to the necessary cross sectoral nature of tourism policy, efforts must also be made to create some vertical institutional structures (at local, regional and national level) as well as horizontal linkages with other relevant policy areas (such as between tourism and environmental policy). This is the only way to achieve a fully integrated tourism policy, meaning sharing the responsibility to provide the formal frameworks (polity), to define the objectives and responsibilities (policy) and to contribute to the political design and to the process (politics) of tourism development [5]. Macedonia is a small country causing a lack of substantial positive economic impacts. The solution may be seen in joint development of a transnational hiking trail as a means of establishing socially and environmentally responsible tourism. So, based on the desk research findings, the study recommends some future actions in the line of reshaping the current network of national trails and designing a new tourism product as an important component of the national tourism supply:

- To introduce new regulations and minimum standards to ensure an appropriate level of quality of service for hiking and mountaineering tourism products;

- To fairly distinguish four major types of funding bodies/organizations: 1) the state; 2) destination management organizations (DMOs); 3) tourism industry associations; and 4) NGOs;

- To introduce investment incentives in the line of enabling local/regional areas to continue towards an independent tourism development far into the future;

- To define tourism-related use of resources and possible environmental impacts;

- To support the positioning of hiking and mountaineering of Macedonia in the region; 
- To strengthen the competitiveness of hiking tourism products offered, by undertaking training programs in tourism-related areas (e. g. guiding, service, hosting);

- To introduce participatory tourism planning in the line of creating structures needed for the distribution of the hiking tourism products;

- To consider the prospective target groups' willingness to pay for a specific hiking product;

- To formulate some planning activities and to project steps in the form of a local tourism strategy, which may serve as a set of guidelines for hiking tourism development in the municipal area;

- To target a specific marketing strategy and to promote it to international tour operators.

\section{LIMITATIONS AND FUTURE WORK}

The research was limited by several factors that can also serve as productive starting points for future work.

- First, the analysis was based on the draft national network of the hiking trails in Macedonia, which despite encompassing more than a hundred hiking trails, it practically omits numerous trails that informally are present. So expending the list of hiking trails may add representation on this issue;

- Secondly, some future research may introduce other aspects of investigation to better identify how to employ hiking trails more efficiently from tourism perspective;

- Finally, the findings are drawn basically on secondary sources, which may be complemented with some primary data obtained from the surveying mountain and hiking experts, officials and representatives of mountain clubs and associations, mountain tourist guides, experts from tourism business etc.;

Yet, this article may assist in better understanding the possibilities for developing hiking tourism in Macedonia, upon which specific development strategies may be set. Overall, the research generates useful findings and points to valuable directions for further work.

\section{ACKNOWLEDGEMENT}

The authors would like to express their gratitude to Prof. Petar Namicev for his assistance in the graphical visualization of the results.

\section{REFERENCES}

[1] APPTRM-Agency for promotion and support of tourism of the Republic of Macedonia. (2016). Draft national network of hiking trails in the Republic of Macedonia (in Macedonian). Skopje.

[2] Bjeljac, Ž., Brankov, J., Jovičić, D., Ćurčić, N. \& Terzić, A. (2012) Valorization of natural and anthropogenic tourist potentials in underdeveloped regions of transition countries. TTEM, $8(3), 1237-1250$.

[3] Boengiu, V. (2012) Evaluation of tourism resources in the Iron Gates natural park in order to identify the potential of tourism development. Annals of the University of Oradea, Geography Series, 22(2), 234-240.

[4] Dimitrov, N., Markoski, B., Petrevska, B. \& Koteski, C. (2017). Mountain tourism in Macedonia: Assessment of the National Park "Pelister", Conference proceedings from the International conference Geobalcanica, Skopje, Macedonia, 20-21 May, 2017, 223-230. 
[5] Farrell, T. A. \& Marion, J. L. (2010). Trail impacts and trail impact management related to visitation at Torres del Paine National Park, Chile. Leisure, 26(1-2), 31-59.

[6] GIZ. (2014). Tourism planning in development cooperation: A handbook - Challenges, Consulting approaches, Practical examples. Federal Ministry of Economic Cooperation and Development, Bonn/Berlin.

[7] Hall, M. C. \& Page, S. (2006). The geography of tourism and recreation: environment, place and space. Psychology Press.

[8] Hinch, T. \& Higham, J. (2011). Sport tourism development. Channel View Publications.

[9] Hugo, L. M. (1999). A comprehensive approach towards the planning, grading and auditing of hiking trails as ecotourism products. Current issues in tourism, 2-3, 138-173.

[10] Kastenholz, E. \& Rodrigues, Á. (2007). Discussing the potential benefits of hiking tourism in Portugal. Anatolia, 18(1), 5-21.

[11] Li, W., Ge, X. \& Liu, C. (2005). Hiking trails and tourism impact assessment in protected area: Jiuzhaigou biosphere reserve, China. Environmental Monitoring and Assessment, 108, 279293.

[12] McNamara, K. E. \& Prideaux, B. (2011). Planning nature-based hiking trails in a tropical rainforest setting. Asia Pacific journal of tourism research, 16(3), 289-305.

[13] Plavša, J. (2007). Sport and recreation tourism (In Serbian). University of Novi Sad, Department of geography, tourism and hotel management, Novi Sad.

[14] Papadimitriou, D. \& Gibson, H. (2008). Benefits sought and realized by active mountain sport tourists in Epirus, Greece: Pre-and post-trip analysis. Journal of Sport and tourism 13(1), 37-60.

[15] Ritchie, B. W. \& Adair, D. (2004). Sport tourism: Interrelationship, impacts and issues. Channel View Publications.

[16] Standeven, J. \& Knop, P. (1999). Sport and recreational tourism. Champaign.

[17] Wolf, I. D., Hagenloh, G. \& Croft, D. B. (2012). Visitor monitoring along roads and hiking trails: How to determine usage levels in tourist sites. Tourism Management, 33, 16-28.

[18] Weed M. (2008). Sports tourism experiences. Journal of sport and tourism, 13(1), 1-4. 